\title{
Tick-borne pathogens in neotropical animals in Trinidad, West Indies
}

\author{
Candice Sant ${ }^{{ }^{*}} \mathbb{0}$, Devon Seunarine ${ }^{1}$, Nadine Holder ${ }^{1}$, Krystal Maharaj ${ }^{1}$, Melanie Vaughan ${ }^{1}$, Shimon Harrus ${ }^{2}$, \\ Ricardo Gutierrez², Yaarit Nachum-Biala², Gad Baneth², Roxanne Charles ${ }^{1}$, Patricia Pow-Brown', \\ Rod Suepaul ${ }^{1}$ and Karla Georges ${ }^{1}$
}

\begin{abstract}
Background: Ticks are important vectors of many pathogens that have contributed to the morbidity and mortality of humans and domestic animals worldwide. Wildlife species have also been implicated as reservoir hosts of a variety of tick-borne pathogens. The objective of this study was to determine which tick-transmitted pathogens were present in the animals harvested from the forest in Trinidad for human consumption.
\end{abstract}

Methods: Thin blood smears from 43 neotropical animals were examined microscopically for tick-borne pathogens. Additionally, DNA extraction and PCR amplification of the 16S rRNA gene were used for amplification of Anaplasma and Ehrlichia while the gltA gene was used for Bartonella, and Rickettsia spp. and the 18S rRNA gene for Babesia, Hepatozoon and Theileria species.

Results: Pathogen DNA was amplified from four samples (a deer, collared peccary and two agoutis). Sequencing of the amplified products from the deer and collared peccary revealed $99.8 \%$ homology to Anaplasma bovis and $98.8 \%$ homology to Ehrlichia canis, respectively. Sequences from two agoutis revealed $90.4 \%$ homology to Theileria spp. DNA of Hepatozoon spp., Bartonella spp. Babesia spp. and Rickettsia spp. was not detected in any of the screened samples. An incidental finding in this study was the presence of bacteria in the blood of animals.

Conclusions: The results indicate that the DNA of tick-transmitted pathogens is present at a frequency of about 10\% in the study population and suggests that neotropical mammals may serve as a source for the potential transmission of tick-borne pathogens to domestic animals and humans. In addition, physicians and hunters should be aware of the symptoms associated with zoonotic tick-borne pathogens so that these infections can be recognised, diagnosed and treated promptly. Bacteria present in carcasses can pose a food safety hazard and hunters should be trained in proper harvesting and handling of carcasses.

Keywords: Anaplasma, Ehrlichia, Hunters, Neotropical animals, Theileria, Tick-borne pathogens, Trinidad

\section{Background}

Ticks are considered to be the second most efficient arthropod vectors of pathogens after mosquitoes [1]. Trinidad is the southernmost island in the Caribbean, located at $10.69^{\circ} \mathrm{N}, 61.22^{\circ} \mathrm{W}$, has a tropical climate, with

*Correspondence: Candice.Sant@sta.uwi.edu

${ }^{1}$ School of Veterinary Medicine, Faculty of Medical Sciences, The University of the West Indies, St Augustine, Trinidad and Tobago

Full list of author information is available at the end of the article similar flora and fauna to the South American mainland, and is ideal for the year-round proliferation of ticks and other arthropod vectors. Argas, Ornithodoros, Amblyomma, Dermacentor, Haemaphysalis, Ixodes and Rhipicephalus spp. have been recovered from humans, bats, canids, felids, equids, ruminants, rodents, marsupials, birds, amphibians and reptiles in Trinidad [2].

Human interaction with wildlife occurs frequently during the hunting season. Hunters overnight in forest original author(s) and the source, provide a link to the Creative Commons licence, and indicate if changes were made. The images or other third party material in this article are included in the article's Creative Commons licence, unless indicated otherwise in a credit line to the material. If material is not included in the article's Creative Commons licence and your intended use is not permitted by statutory regulation or exceeds the permitted use, you will need to obtain permission directly from the copyright holder. To view a copy of this licence, visit http://creativecommons.org/licenses/by/4.0/. The Creative Commons Public Domain Dedication waiver (http://creativeco mmons.org/publicdomain/zero/1.0/) applies to the data made available in this article, unless otherwise stated in a credit line to the data. 
camps in close proximity to their dogs. Neotropical animal carcasses are placed in bags that are carried on the hunter's back thereby further increasing the risk of tick transmission from the carcasses. Hunters also use a "sentry" style of hunting whereby they sit for several hours on a perch in the forest, which places them at increased risk of being bitten by questing ticks, other arthropods and wild animals.

Wildlife have been implicated as reservoir hosts for tick-transmitted pathogens [3-5]. Most infected wildlife species are asymptomatic or may exhibit mild symptoms, which may be difficult to detect [6]. Factors such as deforestation, illegal logging activities, hunting and farming including the rearing of wild animals have resulted in increased contact of humans and domestic animals with wild animals. Indigenous neotropical mammals such as the agouti (Dasyprocta leporina), deer/red brocket deer (Mazama americana), Lappe/spotted paca (Cuniculus paca), manicou/black-eared opossum (Didelphis marsupialis insularis), tattoo/nine-banded armadillo (Dasypus novemcinctus) and wild hog/quenk/collared peccary (Tayassu tajacu) are popular game animals in Trinidad. These animals are also reared in wildlife farming facilities, which are becoming established with increasing frequency [7]. These popular game species are known to harbor ticks that are capable of transmitting diseases between animals [8].

Ehrlichia spp. and Anaplasma spp. are small, gramnegative obligate intracellular bacteria belonging to the family Anaplasmataceae that are transmitted through the saliva of an infested tick, feeding on a host. They infect endothelial cells and leucocytes, specifically granulocytes, monocytes and macrophages of the mammalian hosts [9]. Ehrlichia chaffeensis and E. ewingii can affect humans [10]. Ehrlichia canis, a common tick-borne pathogen present in the canine population of Trinidad and Tobago [11], is transmitted by the brown dog-tick, Rhipicephalus sanguineus (s.l.). Suspected cases of human ehrlichiosis due to species closely related to E. canis have been reported in Venezuela and Costa Rica [12, 13]. Common Anaplasma spp. of domestic animals are A. marginale, A. centrale, A. ovis, A. bovis, A. phagocytophilum and $A$. platys. There is a dearth of published data available on infections with Anaplasma spp. of neotropical animals.

Bartonella spp. are gram-negative intracellular bacteria of zoonotic importance and are mainly transmitted by blood-sucking arthropod vectors such as fleas, ticks, lice and flies [14-17]. Bartonella henselae and B. clarridgeiae have been reported in domestic cats in Trinidad and Tobago using molecular methods [18]. Rickettsia spp. are gram-negative bacilli and are transmitted by fleas, lice and ticks [19]. Reservoir hosts of Rickettsia spp. include the opossum and capybara [20, 21]. Amblyomma cajennense and $R$. sanguineus (s.l.) tick vectors as well as the opossum and capybara are present in Trinidad [2, 22]. The opossum and capybara can thus potentially serve as a source of $R$. rickettsii infection to humans [20,21]. There are no published reports on the presence of Rickettsia spp. in Trinidad.

Babesia spp. and Theileria spp. are protozoan parasites transmitted by ixodid ticks. Piroplasms have been identified in the blood of armadillos, opossums, agoutis, pacas, red brocket and grey brocket deer in the rainforest in French Guiana [23]. Reports based on phylogenetic analyses of the 18S rRNA gene of piroplasms obtained from an agouti, pacas, armadillos and an opossum in Brazil suggest that a new species of Theileria may be infecting pacas, agouti and armadillos and a novel Babesia sp. may be infecting opossums [24]. Hepatozoon spp. are unique protozoan parasites as they are transmitted mainly through the ingestion of arthropods, which are the definitive hosts such as certain species of ticks and fleas [25, 26]. Criado-Fornelio et al. in 2009 identified H. canis as well as an unidentifiable Babesia sp. somewhat related to T. equi in capybaras from Brazil [27]. Hepatozoon canis has been previously identified in the canine population of Trinidad [28].

To date, there are no epidemiological data on which pathogens are present and the molecular characteristics of tick-borne pathogens in neotropical mammals in Trinidad. The health of captured wildlife is also not reported. As $75 \%$ of emerging pathogens are zoonotic and there has been increasing discovery of new tick-borne pathogens in humans, the objective of this study was to screen wildlife captured for human consumption for tick-borne pathogens belonging to the genera Anaplasma, Babesia, Bartonella, Ehrlichia, Hepatozoon, Rickettsia and Theileria using molecular methods.

\section{Methods \\ Hunting}

Hunting is legally permitted in Trinidad on an annual basis for 5 months beginning on the first day of October and ending on the last day of February. All species of neotropical animals screened in this study could be legally hunted during the 2017-2018 and 2018-2019 hunting seasons in Trinidad.

\section{Sample size estimates}

An estimated 30,000 neotropical animals are harvested per year based on receipts submitted to the Ministry of Agriculture, Forestry Division [29]. The Cannon and Roe formula was used to estimate the minimum number 
of animals needed to detect one positive animal. Using an estimated prevalence of $5 \%$ for the detection of tickborne pathogens and 95\% confidence for detecting one positive animal, the estimated sample size using the simple binomial distribution was 59 [30].

\section{Sample collection}

Samples were collected over two consecutive annual hunting periods. Any wildlife carcass submitted for necropsy at the veterinary diagnostic laboratory during this period was also included in the study. Each carcass was examined for ticks. The body condition score was noted for all the animals and assessed according to the criteria outlined in Table 1.

EDTA blood samples were obtained from animals captured by hunters during the 2017-2018 and 2018-2019 hunting seasons. Global positioning system (GPS) coordinates for animals captured from each location were recorded and used to generate maps using the Free and Open Source QGIS software.

Three millilitres of whole blood was collected directly from the jugular vein or heart upon exsanguination of neotropical animals. A thin blood smear was made from each EDTA blood sample and stained with WrightGiemsa for microscopic examination to detect tick-borne pathogens.

Animals were also examined for the presence of ticks. If ticks were present, they were stored and identified using morphological keys [2].

Additionally, a splenic tissue sample was obtained from any neotropical animal submitted to the necropsy laboratory of the School of Veterinary Medicine during the study period.

\section{DNA extraction}

DNA was extracted from $100 \mu \mathrm{l}$ of anticoagulated blood or $25 \mathrm{mg}$ of splenic tissue using the Qiagen DNeasy Blood and Tissue kit (Qiagen, Maryland, USA) according to the manufacturer's instructions. DNA concentrations were determined by measuring the absorbance at $260 \mathrm{~nm}$ (A260) with a NanoVue Spectrophotometer (GE Healthcare, UK Limited).

\section{Amplification of Babesia spp., Theileria spp. and Hepatozoon spp.}

Babesia/Theileria $(\mathrm{B} / \mathrm{T})$ genera were amplified using primers RLBF2/R2, which amplifies a 540-bp fragment of the $18 S$ rRNA gene [31, 32]. Hepatozoon spp. could also be amplified using these primers to give a 400-bp product. Positive samples were further screened for Babesia spp. and Hepatozoon spp. DNA. The $18 S$ rRNA gene of Babesia spp. and Hepatozoon spp. was targeted using the primers Piroplasmid-F/Piroplasmid-R, which amplified a 350-bp fragment [33]. To identify cases of co-infection, positive samples were tested by an additional PCR assay using PIROA/PIROB primers, which amplified a 400-bp fragment of the $18 S$ rRNA gene of the Babesia spp. [34]. DNA from naturally infected dogs with Babesia vogeli (Bab9706) and another dog with Hepatozoon canis infection were used as positive controls. Amplified products were subjected to gel electrophoresis using $1.5 \%$ agarose in TAE buffer pre-stained with ethidium bromide and visualised under UV light.

\section{Amplification of Bartonella spp.}

Real-time PCR was performed to amplify a 340-bp glt $A$ gene fragment using primers $443 \mathrm{~F}$ and $781 \mathrm{R}$ and 300 bp $s s r A$ gene fragment using primers $s s r A F$ and $s s r A R$ (Table 2) with previously described reaction volumes and conditions [35]. DNA extracted from a culture of Bartonella krasnovii served as a positive control.

\section{Amplification of Rickettsia spp.}

Real-time PCR was also used to detect Rickettsia spp. by targeting a 133-bp fragment of the citrate synthase gene (gltA) using primers rico173F and rico173R (Table 2) as previously described [36]. DNA extracted from plasmid containing the rickettsial $g l t A$ gene served as a positive control.

Table 1 Criteria used to assess the body condition score of each captured neotropical animal in this study Adapted and modified from Ullman-Culleré and Foltz [54]

\begin{tabular}{|c|c|c|}
\hline Body condition & Fat stores & Muscling \\
\hline Poor & Barely visible subcutaneous and abdominal fat & $\begin{array}{l}\text { Bony prominences (hips, ribs, pin } \\
\text { bone) highly visible }\end{array}$ \\
\hline Adequate & $\begin{array}{l}\text { Visible subcutaneous and abdominal fat without visual impairment of } \\
\text { the organs }\end{array}$ & Bony prominences barely visible \\
\hline Excessive & $\begin{array}{l}\text { Subcutaneous and abdominal fat causing visual impairment of the } \\
\text { organ }\end{array}$ & Bony prominences not detectable \\
\hline
\end{tabular}


Table 2 Primers and their sequences used in this study

\begin{tabular}{|c|c|c|c|c|c|}
\hline Primers & Sequence $5^{\prime}-3^{\prime}$ & Target gene & Target genera & $\begin{array}{l}\text { Amplicon } \\
\text { size (bp) }\end{array}$ & References \\
\hline $\begin{array}{l}\text { RLB-F2 } \\
\text { RLB-R2 }\end{array}$ & ACACAGGGAGGTAGTGACAAG CTAAGAATTTCACCTCTGACAGT & I8S rRNA & Babesia/Theileria & 540 & [32] \\
\hline $\begin{array}{l}\text { Piroplasmid-F } \\
\text { Piroplasmid-R }\end{array}$ & $\begin{array}{l}\text { CCAGCAGCCGCGGTAATTC } \\
\text { CTTTCGCAGTAGTTYGTCTTTAACAAATCT }\end{array}$ & 18S rRNA & Babesia/Hepatozoon & 350 & [33] \\
\hline PIROA PIROB & AATACCCAATCCTGACACAGGG TTAAATACGAATGCCCCCAAC & 18S rRNA & Babesia & 400 & [34] \\
\hline $\begin{array}{l}\text { 16S8FE } \\
\text { B-GA1B }\end{array}$ & AGAGTTGGATCMTGGYTCAG CGAGTTTGCCGGGACTTYTTC & 16S rRNA & Ehrlichia/Anaplasma & 500 & [37] \\
\hline E.c 16S-fwd E.c. 16S-rev & TCGCTATTAGATGAGCCTACGT GAGTCTGGACCGTATCTCAG & $16 S$ rRNA & Ehrlichia/Anaplasma & 123 & [38] \\
\hline EHR16SD EHR16SR & $\begin{array}{l}\text { GTACCYACAGAAGAAGTCC } \\
\text { TAGCACTCATCGTTTACAGC }\end{array}$ & $16 S$ rRNA & Ehrlichia/Anaplasma & 345 & [40] \\
\hline $\begin{array}{l}443 \mathrm{~F} \\
781 \mathrm{R}\end{array}$ & $\begin{array}{l}\text { GCTATGTCTGCATTCTATCA } \\
\text { CCACCATGAGCTGGTCCCC }\end{array}$ & glt $A$ & Bartonella & 340 & [35] \\
\hline $\begin{array}{l}\text { sSrAF } \\
\text { sSrAR }\end{array}$ & GCTATGGTAATAAATGGACAATGAAATAA GCTTCTGTTGCCAGGTG & ssrA & Bartonella & 300 & [35] \\
\hline $\begin{array}{l}\text { rico173F } \\
\text { rico173R }\end{array}$ & CGACCCGGGTTTTATGTCTA ACTGCTCGCCACTTGGTAGT & gltA & Rickettsia & 133 & [36] \\
\hline
\end{tabular}

\section{Amplification of Anaplasma spp. and Ehrlichia spp.} A portion of the $16 S$ rRNA gene of Anaplasma/Ehrlichia (A/E) genera was amplified by conventional PCR using primers 16S8FE and BGA1B yielding a fragment of approximately 500 bp [37]. Anaplasma marginale was used as the positive control for this reaction. Samples were also subjected to a real-time PCR assay that amplified Anaplasma and Ehrlichia DNA using the primers E.c $16 S$-fwd and E.c. $16 S$-rev, which amplified a 123-bp fragment of the $16 S$ rRNA gene as previously described [38]. Samples were considered positive for E. canis DNA when the cycle threshold values were in the range of 25-40 and the melting curves were identical to those of the positive control [39]. DNA extracted from E. canis cell culture was used as the positive control. Positive samples from the real-time PCR reaction were further analysed by conventional PCR using primers EHR16SD and EHR16SR to amplify a 345-bp fragment of the $16 S$ rRNA gene of the genera Anaplasma and Ehrlichia using the previously described reaction volumes and conditions [40]. PCR products were electrophoresed on $1.5 \%$ agarose gels stained with ethidium bromide and visualised under UV light.

DNA from blood of an uninfected dog was used as a negative control. In addition, non-template controls (NTC) as well as positive controls were included in each reaction in duplicate. Non-template control reactions were done using the same procedures and reagents as described above but without DNA added to the PCR reaction to rule out $\mathrm{PCR}$ contaminations and nonspecific reactions. Sequences of each primer and the targeted genera are given in Table 2.

\section{Sequencing}

Amplicons at 400-500 bp (A/E) and 460-520 bp for B/T were sequenced at Macrogen Inc. (Seoul South Korea), and those at $345 \mathrm{bp}$ for (A/E) PCR were sequenced at Hy Laboratories Ltd. (Rehovot, Israel). Sequences were compared to those deposited in GenBank using the Basic Local Alignment Search Tool (BLAST) [41]. A result was considered positive for a certain pathogen DNA if there was at least a $97 \%$ nucleotide identity with a known GenBank accession number. Three of these sequences were deposited in GenBank databases with accession numbers MZ506884, MZ506850 and MZ506838.

\section{Results}

\section{Sample collection}

A total of 43 blood samples were collected from various neotropical mammalian species over two consecutive hunting seasons from different locations throughout Trinidad (Fig. 1). The majority of the samples collected were from agoutis $(n=22)$ in this study, followed by opossums $(n=15)$, collared peccaries $(n=2)$, ninebanded armadillos $(n=2)$, red brocket deer $(n=1)$ and capybara $(n=1)$. Two neotropical carcasses (red brocket deer and capybara) were submitted for post-mortem examination during the study period. Splenic samples obtained from these two carcasses were included in this study.

The body condition of all animals harvested was classified as adequate and no untoward clinical manifestations of disease were reported. The red brocket deer included in this study was rescued by villagers who found 


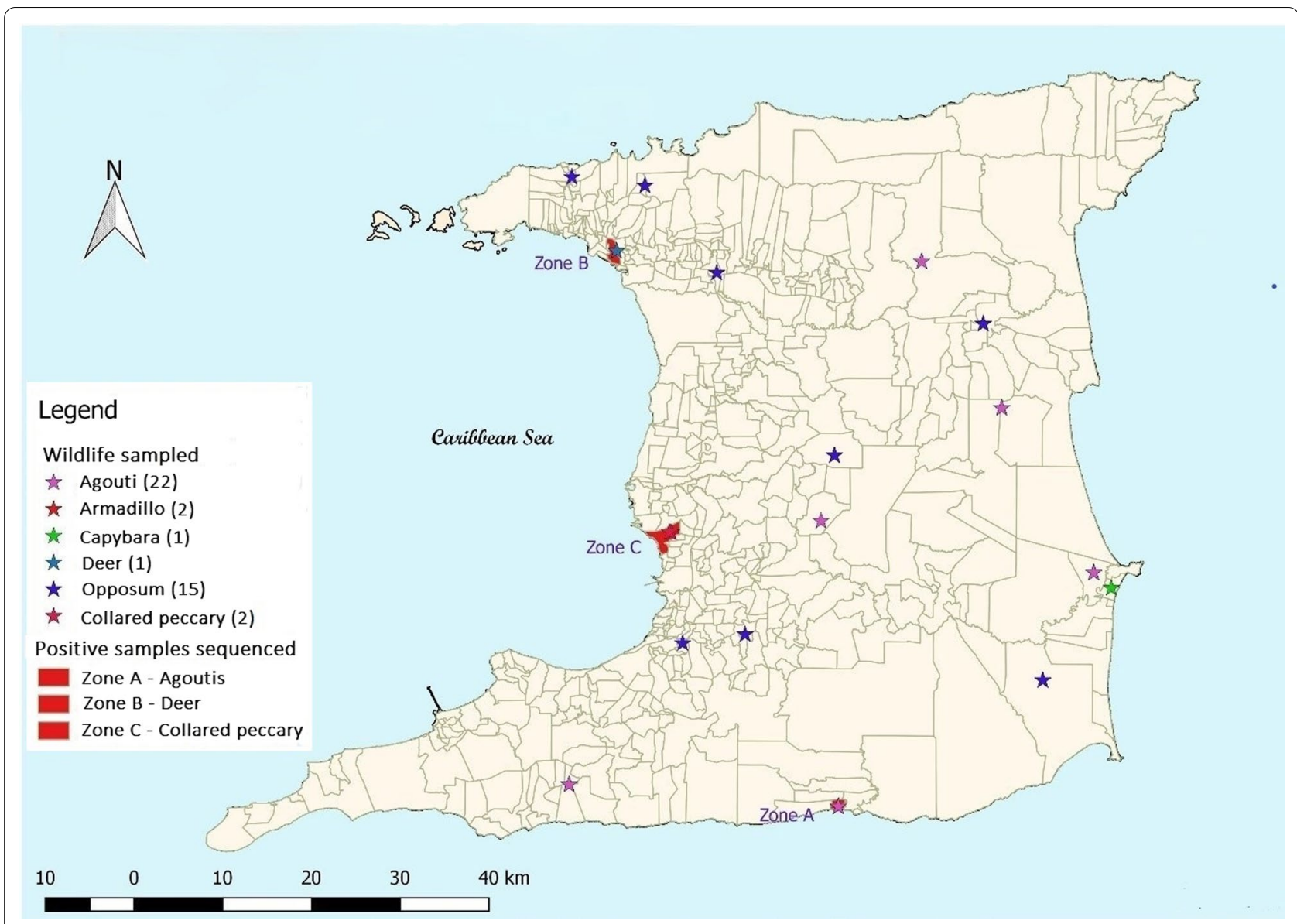

Fig. 1 Map of Trinidad showing sampling sites Map generated using the free and open source QGIS software

the animal in distress near a roadway. The animal was severely infested with ticks, which were predominantly attached to the ears, had pale mucous membranes and voided brown urine. An attending veterinarian reported the deer to be in respiratory distress and it was euthanized. The bladder contained red-brown, slightly opaque urine. There were no significant findings on necropsy of the capybara carcass.

\section{Microscopic examination of blood and splenic smears}

Protozoan parasites were not detected on microscopic examination of all of the blood smears; however, examination of the blood smears from the red brocket deer revealed basophilic bacterial rod-like structures in the cytoplasm of neutrophils. These bacterial rod-like

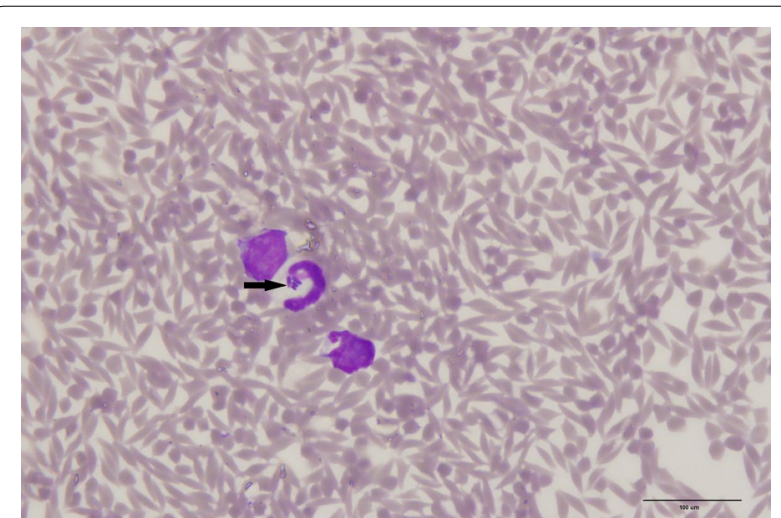

Fig. 2 Basophilic bacterial rod-like inclusions (arrows) observed in the cytoplasm of a neutrophil in the blood. Scale bar represents $100 \mu \mathrm{m}$ 
structures were observed in approximately 1 out of every 80 neutrophils. These structures were also observed in the neutrophils of impression smears of the spleen (Fig. 2). Ten (23\%) blood smears also contained occasional bacterial cocci or rods that were visualised extracellularly, indicating probable contamination.

\section{Tick identification}

Ticks were recovered from one animal (a red brocket deer) and identified as Haemaphysalis juxtakochi. Ticks were not observed on any other animals sampled.

\section{Molecular analyses}

The results for the three PCR protocols (RLB F2/R2, Piroplasmid F/R, PIROA/PIROB) used to evaluate the $18 S$ rRNA gene were in agreement. DNA for Babesial Theileria spp. was only amplified for two adult female agoutis. All other samples were negative. The sequences obtained from the two agoutis were more similar to Theileria than to Babesia spp., with $90.4 \%$ homology to and 99\% query coverage of Theileria sp. OT3 isolate (GenBank: MG930118) from a goat in China.

Two samples (DNA extracted from blood collected from the collared peccary and spleen of the red brocket deer) yielded amplified products of approximately $500 \mathrm{bp}, 123 \mathrm{bp}$ and $325 \mathrm{bp}$ from amplification of the $16 S r R N A$ gene using primers $16 S 8 \mathrm{FE}$ and B-GA1B, E.c. $16 S$-fwd \& E.c. 16S-rev and EHR16SD and EHR16SR, respectively. All samples were negative for Bartonella and Rickettsia DNA.

The sequence obtained from DNA extracted from blood of the collared peccary using primers E.c. 16S-fwd and E.c. 16S-rev had $100 \%$ nucleotide identity to uncultured Ehrlichia spp. (GenBank: MF153980) and 98.8\% nucleotide identity to E. canis (GenBank: MT066094) with $98 \%$ query coverage for both. Sequence of the amplified product obtained from the splenic tissue of the deer using primers 16S8FE/BGA1B revealed 99.8\% nucleotide identity to $A$. bovis sequences from a marsh deer (Blastoceros dichotomus) in Brazil (GenBank: JF952893) and $97.5 \%$ nucleotide identity to an $A$. bovis sequence obtained from a goat in China (GenBank: MH255939).

\section{Discussion}

The neotropical mammalian wildlife of Trinidad has long remained unexplored with respect to production and scientific research. However, within recent years there has been an increase in neotropical animal production as their contributions toward employment, food security and conservation needs of humans are being realised [7]. Wildlife-associated infectious diseases are also becoming increasingly important because of the rise in interaction of these species with humans, domestic animals and livestock. This is the first report on the use of molecular methods to screen tick-borne pathogens in neotropical animals in Trinidad. As little is known about the infectious agents present in the neotropical animal population, the findings uncovered in this study are of major importance to elucidate the pathogens that may have a zoonotic potential.

Theileria equi found in equids is the only Theileria spp. reported in Trinidad [42, 43]. BLAST analyses showed that the sequences obtained from the amplified products of the two agoutis were more similar to Theileria spp. than Babesia spp. It should also be noted that the two sequences were not closely related to $T$. equi from Trinidad as they had $92.3 \%$ nucleotide identity to and $71 \%$ query coverage of $T$. equi sequences from Trinidad (Genbank: KY053284 and KY053283). The results from this study suggest that another Theileria sp. may be present in the wildlife population of Trinidad and has to be further investigated. Although Hepatozoon spp. have been previously reported in capybara and paca, it has not been widely reported in neotropical animals. Furthermore, it was not detected in this study, which is in agreement with other published reports. Hepatozoon species-specific primers were not used; however, the fragment generated by Hepatozoon DNA is $400 \mathrm{bp}$ while that of Babesia /Theileria DNA is 540 bp. Further work using a larger sample size is needed. Criado-Fornelio et al. [44] did not detect Hepatozoon spp. in a sample of 15 opossums in Brazil. A novel Hepatozoon species was identified from the lung tissue of a lowland paca in Brazil; however, that study failed to detect Hepatozoon DNA in samples obtained from nine-banded armadillos $(n=32)$, agoutis $(n=2)$, collared peccaries $(n=11)$, opossums $(n=19)$ and red brocket deer $(n=3)$ [24].

Deer have been identified as important reservoirs of Anaplasma spp. and Ehrlichia spp. including A. bovis [45]. Stressors such as poor nutrition, handling, harsh weather or environmental conditions may result in clinical manifestations of tick-borne disease [46]. The hard tick, Haemaphysalis juxtakochi, parasitise deer, paca and the collared peccary and is associated with the transmission of several Rickettsia spp. [47]. There is limited information on the reservoir hosts and tick vectors of $E$. chaffeensis on the South American continent [48]. This tick-borne pathogen was also reported in the marsh deer (Blastocerus dichotomus) population in Brazil and Argentina [48]. The spleen of the deer was positive for $A$. bovis DNA based on molecular analysis; however, no DNA of this organism was amplified from the blood. The reason for this could be that the level of bacteraemia was below the PCR assay's sensitivity and/or the organism may have been sequestered in the spleen and not present in 
the central circulation [49]. The spleen removes aged or parasitised blood cells and causes haemoconcentration of blood, which may account for the detection of Anaplasma sp. DNA only in the splenic tissue. This study also demonstrated that splenic tissue, in addition to whole blood samples, should be harvested to increase the sensitivity of detection of tick-borne pathogens of neotropical animals using molecular methods, as previously shown for domestic animals $[49,50]$.

The identification of DNA of Bartonella spp. directly from the blood of animals or humans using molecular techniques can be challenging as it lacks sensitivity even in the presence of bacteraemia [51]. This is possibly one of the reasons for the negative PCR results obtained in this study. Some researchers recommend that suspected samples should undergo an enrichment culture before the PCR amplification to improve the sensitivity in detecting Bartonella spp. from the blood of animals and humans $[51,52]$. Using whole blood is less sensitive than using tissue samples for the detection of Rickettsia spp. when there are low numbers of bacteria circulating in the blood, especially in the absence of advanced disease and severe infections [53].

The number of samples and species collected in this study were completely dependent on the participating hunters and their preferred species to hunt. Hunters were reluctant to participate in this study, restricting the number of collected samples. Trinidad also experienced persistent torrential rainfall and severe flash flooding in its Northern, Central and Southern regions during the study period. Due to this inclement weather and the terrain conditions thereafter, data collection was postponed for several months until participating hunters found conditions to be safe and accessible for hunting. This unexpected and prolonged period of inactivity greatly impacted the number of samples collected during this study.

The case of the red brocket deer shows that hunters will encounter animals of varying health and animals with ticks. The red brocket deer might have been consumed if this chance intervention by villagers had not occurred. Hunters must be educated on recognising normal and abnormal animals and should be aware of the potential risks associated with contact with wildlife and carcasses infested with ectoparasites. Ten blood smears contained occasional extracellular bacterial cocci or rods, which may be attributed to bacterial contamination during the slaughter process. This incidental finding is of public health significance as it indicates that slaughter practices may not be hygienic, leading to haematological spread of bacterial contaminants and cross contamination of surfaces. These factors can lead to a reduction in wholesomeness of the carcass and highlights the potential for a food safety hazard. Therefore, hunters should also be trained in safe animal slaughter procedures, including cleaning tools between butchering to avoid cross contamination. With the broad gaps of knowledge surrounding Trinidadian wildlife, this study serves as a starting point to encourage further investigations into the health of the neotropical population of the rainforest, which has a very close relationship with Trinidadian society and culture.

\section{Conclusion}

The present study confirmed the presence of tick-borne pathogens in wildlife captured for human consumption in Trinidad, including $A$. bovis in a deer, a Theileria sp. in agoutis and an Ehrlichia sp. (related to E. canis) in a collared peccary. Further research is needed to investigate the identity of these species and their medico-veterinary significance.

\section{Abbreviations}

A/E: Anaplasma/Ehrlichia; B/T: Babesia/Theileria; bp: Base pairs; BLAST: Basic Local Alignment Search Tool; DNA: Deoxyribonucleic acid; EDTA: Ethylenediaminetetraacetic acid; GPS: Global positioning system; NTC: Non-template control; rRNA: Ribosomal ribonucleic acid; QGIS: Quantum Geographic Information System; TAE: Tris-acetate-EDTA; UV: Ultraviolet.

\section{Acknowledgements \\ Thanks to Mr. Brian Sandford for constructing the map.}

\section{Authors' contributions}

$\mathrm{KG}, \mathrm{CS}, \mathrm{YNB}, \mathrm{SH}, \mathrm{DS}, \mathrm{KM}, \mathrm{MV}$ and $\mathrm{NH}$ contributed to study design and writing of the manuscript. PPB, YNB, CS, GB and RG contributed to the molecular validation. $\mathrm{RS}, \mathrm{RC}, \mathrm{CS}, \mathrm{DS}, \mathrm{KM}, \mathrm{MV}$ and $\mathrm{NH}$ contributed to data collection and evaluation. All authors contributed to editing of the manuscript. All authors read and approved the final manuscript.

\section{Funding}

Funding for this research project was provided by the School of Veterinary Medicine, the University of the West Indies and Koret School of Veterinary Medicine, The Hebrew University of Jerusalem.

\section{Availability of data and materials}

The data supporting the conclusions of this article are included within the article. Raw data can be shared with researchers upon a specific request.

\section{Declarations}

\section{Ethics approval and consent to participate}

Ethical approval was obtained from the Faculty of Medical Sciences, The University of the West Indies Ethics Committee (approval no. CRECSA.0127/12/2019). Consent to participate is not required for this study as blood and splenic samples were obtained from neotropical animals that hunters caught during two consecutive hunting seasons.

Consent for publication

Not applicable.

Competing interests

The authors declare that they have no competing interests. 


\section{Author details}

'School of Veterinary Medicine, Faculty of Medical Sciences, The University of the West Indies, St Augustine, Trinidad and Tobago. ${ }^{2}$ Koret School of Veterinary Medicine, The Hebrew University of Jerusalem, Rehovot, Israel.

Received: 5 October 2021 Accepted: 28 January 2022 Published online: 19 February 2022

\section{References}

1. Parola P, Raoult D. Ticks and tickborne bacterial diseases in humans: an emerging infectious threat. Clin Infect Dis. 2001;32:897-928.

2. Basu AK, Charles R. Ticks of Trinidad and Tobago-an overview. Amsterdam: Elsevier; 2017.

3. Irwin PJ. Canine babesiosis: from molecular taxonomy to control. Parasit Vectors. 2009;2:S4.

4. Tsao Jl, Hamer SA, Han S, Sidge JL, Hickling GJ. The contribution of wildlife hosts to the rise of ticks and tick-borne diseases in North America. J Med Entomol. 2021:58:1565-87.

5. Mongruel A, Benevenute J, André M, Carrasco A, Machado R, Seki M. Molecular characterization of Anaplasma sp. in free-living gray brockets (Mazama gouazoubira). Vector Borne Zoonotic Dis. 2017;17:165-71.

6. Kuttler K. Anaplasma infections in wild and domestic ruminants: a review. J Wildl Dis. 1984;20:12-20.

7. Belgraves V. Trinidad and Tobago Fifth National Report to the United Nations Convention on Biological Diversity. Trinidad and Tobago; 2016:1-225.

8. Sonenshine DE, Roe RM. Biology of ticks, vol. 2. Oxford: Oxford University Press; 2013.

9. de Aguiar DM. Ehrlichiosis. In: Bayry J, editor. Emerging and re-emerging infectious diseases of livestock. Berlin: Springer; 2017. p. 365-75.

10. Dumler JS, Barbet AF, Bekker C, Dasch GA, Palmer GH, Ray SC, et al. Reorganization of genera in the families Rickettsiaceae and Anaplasmataceae in the order Rickettsiales: unification of some species of Ehrlichia with Anaplasma, Cowdria with Ehrlichia and Ehrlichia with Neorickettsia, descriptions of six new species combinations and designation of Ehrlichia equi and "HGE agent" as subjective synonyms of Ehrlichia phagocytophila. Int J Syst Evol Microbiol. 2001;51:2145-65.

11. Georges K, Ezeokoli CD, Newaj-Fyzul A, Campbell M, Mootoo N, Mutani A, et al. The application of PCR and reverse line blot hybridization to detect arthropod-borne hemopathogens of dogs and cats in Trinidad. Ann N Y Acad Sci. 2008;1149:196-9.

12. Bouza-Mora L, Dolz G, Solórzano-Morales A, Romero-Zuñiga JJ, SalazarSánchez L, Labruna MB, et al. Novel genotype of Ehrlichia canis detected in samples of human blood bank donors in Costa Rica. Ticks Tick Borne Dis. 2017;8:36-40.

13. Perez M, Bodor M, Zhang C, Xiong Q, Rikihisa Y. Human infection with Ehrlichia canis accompanied by clinical signs in Venezuela. Ann NY Acad Sci. 2006;1078:110-7.

14. Ellis BA, Rotz LD, Leake J, Samalvides F, Bernable J, Ventura G, et al. An outbreak of acute bartonellosis (Oroya fever) in the Urubamba region of Peru, 1998. Am J Trop Med Hyg. 1999;61:344-9.

15. Sasaki T, Poudel SKS, Isawa H, Hayashi T, Seki N, Tomita T, et al. First molecular evidence of Bartonella quintana in Pediculus humanus capitis (Phthiraptera: Pediculidae), collected from Nepalese children. J Med Entomol. 2006:43:110-2.

16. Chomel BB, Kasten RW, Floyd-Hawkins K, Chi B, Yamamoto K, RobertsWilson J, et al. Experimental transmission of Bartonella henselae by the cat flea. J Clin Microbiol. 1996;34:1952-6.

17. Chang C, Chomel BB, Kasten R, Romano V, Tietze N. Molecular evidence of Bartonella spp. in questing adult Ixodes pacificus ticks in California. J Clin Microbiol. 2001;39:1221-6.

18. Rampersad JN, Watkins JD, Samlal MS, Deonanan R, Ramsubeik S, Ammons DR. A nested-PCR with an internal amplification control for the detection and differentiation of Bartonella henselae and B. clarridgeiae: an examination of cats in Trinidad. BMC Infect Dis. 2005;5:63.

19. Azad AF, Beard CB. Rickettsial pathogens and their arthropod vectors. Emerg Infect Dis. 1998;4:179.
20. Luz HR, Costa FB, Benatti HR, Ramos VN, Serpa MC, Martins TF, et al. Epidemiology of capybara-associated Brazilian spotted fever. PLoS Negl Trop Dis. 2019;13:e0007734.

21. Ueno TEH, Cutolo AA, Martins TF, Moraes-Filho J, Azevedo SS, Labruna MB. Rickettsial infection in equids, opossums and ticks in the municipality of Monte Mor, state of São Paulo, Brazil. Rev Bras Parasitol Vet. 2020;29:e015420.

22. Aitken TH, Spence L, Jonkers AH, Downs WG. A 10-year survey of Trinidadian arthropods for natural virus infections (1953-1963). J Med Entomol. 1969;6:207-15.

23. de Thoisy B, Michel J-C, Vogel I, Vié J-C. A survey of hemoparasite infections in free-ranging mammals and reptiles in French Guiana. J Parasitol. 2000;86:1035-40.

24. Soares HS, Marcili A, Barbieri AR, Minervino AH, Moreira TR, Gennari SM, et al. Novel piroplasmid and Hepatozoon organisms infecting the wildlife of two regions of the Brazilian Amazon. Int J Parasitol Parasites Wildl. 2017;6:115-21.

25. Smith TG. The genus Hepatozoon (apicomplexa: adeleina). J Parasitol. 1996:82:565-85.

26. Watkins RA, Moshier SE, Pinter AJ. The flea, Megabothris abantis: an invertebrate host of Hepatozoon sp. and a likely definitive host in Hepatozoon infections of the montane vole, Microtus montanus. J Wildl Dis. 2006;42:386-90.

27. Criado-Fornelio A, Buling A, Casado N, Gimenez C, Ruas J, Wendt L, et al. Molecular characterization of arthropod-borne hematozoans in wild mammals from Brazil. Venezuela and Spain Acta Parasitol. 2009:54:187-93.

28. Sant C, Georges KC, Pow-Brown P. Novel incidental finding of Hepatozoon canis infection in two dogs of the same household in Trinidad, West Indies. Vet Parasitol Reg Stud Reports. 2017;9:98-103.

29. Wildlife division, Ministry of Agriculture, Land, and, Fisheries. Number of neo-tropical animals harvested per year in Trinidad and Tobago. Trinidad; 2020.

30. Sergeant ESG. Epitools epidemiological calculators. Ausvet. 2018. http:// epitools.ausvet.com.au. Accessed 15 Jun 2020

31. Gubbels J, De Vos A, Van der Weide M, Viseras J, Schouls L, De Vries E, et al. Simultaneous detection of bovine Theileria and Babesia species by reverse line blot hybridization. J Clin Microbiol. 1999;37:1782-9.

32. Georges K, Loria G, Riili S, Greco A, Caracappa S, Jongejan F, et al. Detection of haemoparasites in cattle by reverse line blot hybridisation with a note on the distribution of ticks in Sicily. Vet Parasitol. 2001;99:273-86.

33. Tabar MD, Altet $L$, Francino $O$, Sánchez A, Ferrer L, Roura X. Vector-borne infections in cats: molecular study in Barcelona area (Spain). Vet Parasitol. 2008;151:332-6.

34. Olmeda A, Armstrong P, Rosenthal B, Valladares B, Del Castillo A, De Armas F, et al. A subtropical case of human babesiosis. Acta Trop. 1997:67:229-34.

35. Sofer S, Gutiérrez R, Morick D, Mumcuoglu K, Harrus S. Molecular detection of zoonotic bartonellae (B. henselae, B. elizabethae and B. rochalimae) in fleas collected from dogs in Israel. Med Vet Entomol. 2015;29:344-8.

36. Harrus S, Perlman-Avrahami A, Mumcuoglu K, Morick D, Baneth G. Molecular detection of Rickettsia massiliae, Rickettsia sibirica mongolitimonae and Rickettsia conorii israelensis in ticks from Israel. Clin Microbiol Infect. 2011;17:176-80.

37. Bekker CP, de Vos S, Taoufik A, Sparagano OA, Jongejan F. Simultaneous detection of Anaplasma and Ehrlichia species in ruminants and detection of Ehrlichia ruminantium in Amblyomma variegatum ticks by reverse line blot hybridization. Vet Microbiol. 2002;89:223-38.

38. Peleg O, Baneth G, Eyal O, Inbar J, Harrus S. Multiplex real-time qPCR for the detection of Ehrlichia canis and Babesia canis vogeli. Vet Parasitol. 2010;173:292-9.

39. Bustin SA, Benes V, Garson JA, Hellemans J, Huggett J, Kubista M, et al. The MIQE guidelines: minimum information for publication of quantitative real-time PCR experiments. Clin Chem. 2009;55:611-22.

40. Parola P, Roux V, Camicas JL, Baradji I, Brouqui P, Raoult D. Detection of ehrlichiae in African ticks by polymerase chain reaction. Trans R Soc Trop Med Hyg. 2000;94:707-8.

41. Altschul SF, Gish W, Miller W, Myers EW, Lipman DJ. Basic local alignment search tool. J Mol Biol. 1990;215:403-10. 
42. Georges KC, Ezeokoli CD, Sparagano O, Pargass I, Campbell M, D’Abadie $R$, et al. A case of transplacental transmission of Theileria equi in a foal in Trinidad. Vet Parasitol. 2011;175:363-6.

43. Sant C, d'Abadie R, Pargass I, Basu AK, Asgarali Z, Charles RA, et al. Prospective study investigating transplacental transmission of equine piroplasmosis in thoroughbred foals in Trinidad. Vet Parasitol. 2016;226:132-7.

44. Criado-Fornelio A, Ruas J, Casado N, Farias NAR, Soares M, Müller G, et al, New molecular data on mammalian Hepatozoon species (Apicomplexa: Adeleorina) from Brazil and Spain. J Parasitol. 2006:92:93-9.

45. Kawahara M, Rikihisa Y, Lin Q, Isogai E, Tahara K, Itagaki A, et al. Novel genetic variants of Anaplasma phagocytophilum, Anaplasma bovis, Anaplasma centrale, and a novel Ehrlichia sp. in wild deer and ticks on two major islands in Japan. Appl Environ Microbiol. 2006;72:1102-9.

46. Li Y, Chen Z, Liu Z, Liu J, Yang J, Li Q, et al. Molecular survey of Anaplasma and Ehrlichia of red deer and sika deer in Gansu, China in 2013. Transbound Emerg Dis. 2016;63:e228-36.

47. Kohls GM. Records and new synonymy of New World Haemaphysalis ticks, with descriptions of the nymph and larva of H. juxtakochi Cooley. J Parasitol. 1960;46:355-61.

48. Machado RZ, Duarte JM, Dagnone AS, Szabó MP. Detection of Ehrlichia chaffeensis in Brazilian marsh deer (Blastocerus dichotomus). Vet Parasitol. 2006;139:262-6.

49. Harrus S, Kenny M, Miara L, Aizenberg I, Waner T, Shaw S. Comparison of simultaneous splenic sample PCR with blood sample PCR for diagnosis and treatment of experimental Ehrlichia canis infection. Antimicrob Agents Chemother. 2004;48:4488-90.

50. Harrus S, Waner T, Aizenberg I, Foley JE, Poland AM, Bark H. Amplification of ehrlichial DNA from dogs 34 months after infection with Ehrlichia canis. J Clin Microbiol. 1998;36:73-6.

51. Kosoy M, Bai Y, Sheff K, Morway C, Baggett H, Maloney SA, et al. Identification of Bartonella infections in febrile human patients from Thailand and their potential animal reservoirs. Am J Trop Med Hyg. 2010;82:1140-5.

52. Pérez C, Maggi RG, Diniz PP, Breitschwerdt EB. Molecular and serological diagnosis of Bartonella infection in 61 dogs from the United States. J Vet Intern Med. 2011;25:805-10.

53. Centers for Disease Control and Prevention. Diagnosis and management of tickborne rickettsial diseases; Rocky Mountain spotted fever, ehrlichioses, and anaplasmosis-United States: a practical guide for physicians and other health-care and public health professional. MMWR. 2006;5:1-24.

54. Ullman-Culleré MH, Foltz CJ. Body condition scoring: a rapid and accurate method for assessing health status in mice. Comp Med. 1999:49:319-23.

\section{Publisher's Note}

Springer Nature remains neutral with regard to jurisdictional claims in published maps and institutional affiliations.

Ready to submit your research? Choose BMC and benefit from:

- fast, convenient online submission

- thorough peer review by experienced researchers in your field

- rapid publication on acceptance

- support for research data, including large and complex data types

- gold Open Access which fosters wider collaboration and increased citations

- maximum visibility for your research: over $100 \mathrm{M}$ website views per year

At BMC, research is always in progress.

Learn more biomedcentral.com/submissions 